\title{
Growth, Mineral Deposition, and Physiological Responses of Broiler Chickens Offered Honey in Drinking Water during Hot-Dry Season
}

\author{
Monsuru Oladimeji Abioja, Kabir Babatunde Ogundimu, Titilayo Esther Akibo, \\ Kayode Ezekiel Odukoya, Oluwatosin Olawanle Ajiboye, John Adesanya Abiona, \\ Tolulope Julius Williams, Emmanuel Oyegunle Oke, and Olusegun Ayodeji Osinowo
}

\author{
Department of Animal Physiology, College of Animal Science and Livestock Production, University of Agriculture, \\ Abeokuta PMB 2240, Nigeria
}

Correspondence should be addressed to Monsuru Oladimeji Abioja, dimejiabioja@yahoo.com

Received 31 March 2012; Revised 15 June 2012; Accepted 20 June 2012

Academic Editor: Eugene S. Morton

Copyright (C) 2012 Monsuru Oladimeji Abioja et al. This is an open access article distributed under the Creative Commons Attribution License, which permits unrestricted use, distribution, and reproduction in any medium, provided the original work is properly cited.

\begin{abstract}
Growing broilers were offered either $0(0 \mathrm{H}), 10(10 \mathrm{H}), 20 \mathrm{~mL}(20 \mathrm{H})$ honey, or $0.5 \mathrm{~g}$ vitamin C/litre water (AA) during hot-dry season. Honey had no significant $(P>0.05)$ effect on feed intake $(\mathrm{FI})$, weight gain $(\mathrm{WG})$, feed conversion ratio (FCR), water intake (WI), survival (SURV), dressed percentage (DRE), breas tmeat (BRE), gizzard (GIZ), drumstick (DRU), shank (SHA), thigh (THI), tibia volume (VOL), and magnesium (MAG). Effect of honey was significant $(P<0.05)$ on tibial weight (WEI), density (DEN), calcium (CAL), and phosphorus (PHO). WEI and DEN increased with increasing level of honey. $20 \mathrm{H}$ broilers had higher $\mathrm{CAL}$ than $\mathrm{OH}$ and $10 \mathrm{H}$ groups. Broilers offered honey had significantly lower PHO than AA group but the difference between honey groups was not significant. Honey significantly affected $\mathrm{PR}(P<0.001)$ and $\mathrm{HR}(P<0.001)$ but not RT $(P>0.005)$. Higher dose of honey lowered PR and HR. Honey significantly $(P<0.05)$ increased THY but LIV, KID, LUN, SPL, BUR, and HEA were not significantly $(P>0.05)$ affected. $20 \mathrm{H}$ broilers had higher THY than $0 \mathrm{H}$ and $10 \mathrm{H}$ groups. In conclusion, honey did not affect growth but might improve broilers' welfare when offered up to $20 \mathrm{H}$ during hot periods.
\end{abstract}

\section{Introduction}

The fast-growing commercial broilers are more sensitive to high temperature during the growing-finishing phase than starter phase. This may be adduced to the inferior development of the cardiovascular, respiratory, and thermoregulatory systems compared with their high rate of growth [1]. They do not possess sweat glands [2, 3]. Environmental temperature in South-Western Nigeria is often higher than 18$21^{\circ} \mathrm{C}[4]$ recommended for optimal productivity of growing broiler chickens [5]. Often, growth and welfare of the birds are compromised [6-9] and survival lowered [10] because of the birds responses to the stressor. Post [11] reported that high environmental temperature leads to excretion of some minerals like $\mathrm{Ca}, \mathrm{Fe}, \mathrm{Zn}$, and results in decreased bone strength. HS showed deleterious effects by decreasing length and width of tibia, ash and its strength [12]. Fastgrowing broilers as a result typically have significant skeletal problems and may suffer lameness. Thus optimal broiler production in the hot season therefore requires an adequate and appropriate management system that can reduce the effects of HS to the minimum. Abioja and colleagues [13] had earlier reported that addition of vitamin $\mathrm{C}$ to broilers' drinking water could reduce rectal temperature and panting rate during afternoon in open-sided poultry house during hot-dry season. This agrees with the reports of previous works on effects of vitamin C in heat-stressed birds [14-18]. Vitamin C helps in inhibiting the secretion and release of corticosterone, which may be cytocytic at high concentration during stress episodes. 
There are various plant materials in nature which had been suggested that could be of help in reducing the effects of HS in farm animals. Ramnath et al. [19] used Brahma Rasayana, a nontoxic poly herbal preparation while others used extract from propolis, a plant gum-like waxy resin collected by honey bees to ameliorate the effects of HS in broilers. The authors found these to be efficacious. Chen et al. [20] reported that pretreating of cyclists with propolis extract reversed or reduced the hyperthermiainduced effects, including reduced cell death, inhibition of the overproduction of superoxide, and an attenuation of the depletion of glutathione in the exercising cyclists. Wang et al. [21] worked and reported on the use of bee pollen. Diets supplemented with $1.5 \%$ bee pollen could boost the early development of thymus and Fabrici bursa, retard the bursa degeneration, and promote the immune response of spleen chickens. These include ginger root [22] tried ginger root in heat-stressed chickens. The proposal of all these plant materials to ameliorate the effects of HS was based on their content of substances that have antioxidant properties. Honey is a good example of natural substance that contains phytochemicals such as vitamin C, thiamine, riboflavin, pyridoxine, pantothenic acid, nicotinic acid, phenolic compounds, and enzymes glucose oxidase, catalase, and peroxidase. In human beings, honey has been reported to have antioxidant [23] and antibacterial activities [24, 25]. Adebiyi et al. [26] had earlier reported that Nigerian honey was quite rich in minerals. Twelve elements- $\mathrm{K}, \mathrm{Ca}, \mathrm{Ti}, \mathrm{Cr}$, $\mathrm{Mn}, \mathrm{Fe}, \mathrm{Ni}, \mathrm{Cu}, \mathrm{Zn}, \mathrm{Se}, \mathrm{Br}$ and $\mathrm{Rb}$ - were detected in honey sampled in South-West and South-East Nigeria. Reports on the use of honey in chickens are not readily available. This study is therefore aimed at determining the efficacy of honey in improving the growth rate and physiological welfare of broilers reared during hot-dry season.

\section{Materials and Methods}

2.1. Experimental Location and Meteorological Observations. The research was carried out at the Poultry Unit of the Teaching and Research Farms, University of Agriculture, Abeokuta, Nigeria (latitude $7^{\circ} 13^{\prime} 49.46^{\prime \prime} \mathrm{N}$; longitude $3^{\circ}$ $26^{\prime} 11.98^{\prime \prime} \mathrm{E}$ and altitude 76 metre above sea level). The climate is humid and located in the rain forest vegetation zone of western Nigeria. The daily minimum, maximum, and mean ambient temperatures, relative humidity and wetand dry-bulb temperatures at the level of the birds in the pen at $0800 \mathrm{~h}$ and $1400 \mathrm{~h}$ were monitored throughout the experimental period. The temperature-humidity index was determined from relative humidity and wet- and dry-bulb temperature data.

2.2. Experimental Animals and Management. The birds at d21 were randomly allotted to 12 groups of 11 birds each and allowed adjust to the pens for a week. Each 3 groups received one of 4 treatments: either $0 \mathrm{~mL}(0 \mathrm{H}$; negative control), $10 \mathrm{~mL}(10 \mathrm{H}), 20 \mathrm{~mL}(20 \mathrm{H})$ honey or $0.5 \mathrm{~g}$ vitamin C (AA; positive control) per litre water from d28 to d56. Water and standard finisher mash were given ad libitum. The composition of the diet is shown in Table 1.

\subsection{Data Collection}

2.3.1. Growth Performance. Liveweight of the birds in each replicate was monitored with a sensitive scale every week during the experiment. Records on daily weight gain (WG), feed intake (FI), water intake (WI), and survivability (SURV) were kept. Feed conversion ratio (FCR) was calculated as the ratio of gain to feed. At d56, three birds per replicate were sacrificed by exsanguinations. The birds were processed by scalding and weight of the cut parts measured. Cut parts considered include breast meat (BRE), gizzard (GIZ), drumstick (DRU), shank (SHA), and thigh (THI).

2.3.2. Physiological Responses. Daily rectal temperature (RT) was measured with aid of Jorita digital thermometer (model: ECT-5) with $\pm 0.1^{\circ} \mathrm{C}$ accuracy, inserted into the rectum of the birds and held till the thermometer beeped. Panting rate (PR) was taken as the number of flank movement per minute. A count was taken as a cycle of in and out movement. A stethoscope was placed on the chest region to monitor the heart rate (HR) per minute.

2.3.3. Mineral Deposition in Tibiae and Relative Weight of Organs. Right and left tibiae were removed and boiled to detach all flesh. The weight and volume of the fresh bones were taken. The bones were oven-dried to a constant weight before analyzed to determine for calcium, phosphorus and magnesium contents. Weight of liver (LIV), kidney (KID), lungs (LUN), spleen (SPL), bursa of Fabricius (BUR), thymus (THY), and heart (HEA) was taken and relative weight was determined as a percent of liveweight of the birds.

2.4. Statistical Design and Analysis. Data on feed intake (FI), weight gain (WG), feed conversion ratio (FCR), water intake (WI), survivability (SURV), percent dressed weight (DRE), percent breast meat (BRE), percent gizzard (GIZ), percent drumstick (DRU), percent shank (SHA), percent thigh (THI), tibial volume (VOL), tibial weight (WEI), tibial density (DEN), calcium (CAL), phosphorus (PHO), and magnesium (MAG) content of tibia bones, rectal temperature (RT), panting rate (PR), heart rate (HR), relative weight of liver (LIV), kidney (KID), lungs (LUN), spleen (SPL), bursa of Fabricius (BUR), thymus (THY), and heart (HEA) were subjected to one-way analysis of variance using GLM method of SYSTAT statistical package [27], with level of significance taken as $P \leq 0.05$. The statistical model is $Y_{i j}=$ $\mu+\mathrm{M}_{i}+\Sigma_{i j}$ : where $\mathrm{Y}_{i j}=$ yield; $\mu=$ population mean, $\mathrm{M}_{i}=i$ th effect due to treatment $(i=1,2,3,4)$, and $\Sigma_{i j}=$ residual error. Means observed to be significantly different were subjected to mean separation using Tukey procedure of SYSTAT [27].

\section{Results}

Summary of the climatic measurement is presented in Table 2. The morning temperature and temperaturehumidity index were lower in value than the values for the afternoon. Opposite was the case for relative humidity. Table 3 shows the result of the effect of honey on growth 
TABle 1: Composition of diets for broiler (starter and finisher phases).

\begin{tabular}{lcc}
\hline Ingredients & Starter phase (\%) & Finisher phase (\%) \\
\hline Maize & 46.00 & 50.00 \\
Soybean meal & 18.50 & 12.00 \\
Groundnut cake & 15.00 & 11.00 \\
Fishmeal & 2.00 & 2.00 \\
Wheat offal & 12.45 & 19.05 \\
Bone meal & 2.00 & 2.00 \\
Oyster shell & 3.00 & 3.00 \\
Salt & 0.25 & 0.25 \\
$*$ Premix & 0.25 & 0.25 \\
Methionine & 0.30 & 0.25 \\
Lysine & 0.25 & 0.20 \\
\hline & 100 & 100 \\
\hline Calculated: & & \\
Crude protein (\%) & 23.05 & 19.91 \\
ME (MJ/Kg) & 11.73 & 11.71 \\
Ether extract $(\%)$ & 3.93 & 3.89 \\
Crude fibre (\%) & 3.67 & 3.79 \\
Calcium $(\%)$ & 1.75 & 1.74 \\
Phosphorus $(\%)$ & 0.43 & 0.41 \\
\hline & &
\end{tabular}

* $1 \mathrm{~kg}$ of premix contains: vitamin A: $10,000,000 \mathrm{IU}$; vitamin D3: 2,000,000 IU; vitamin E: 20,000 IU; vitamin $\mathrm{K}: 2,250 \mathrm{mg}$; thiamine B1: $1,750 \mathrm{mg}$; riboflavin $\mathrm{B} 2: 5,000 \mathrm{mg}$; pyridoxine $\mathrm{B} 6: 2,750 \mathrm{mg}$; niacin: 27,500 mg; vitamin B12: $15 \mathrm{mg}$; pantothenic acid: 7,500 mg; folic acid: 7,500 mg; biotin: $50 \mathrm{mg}$; choline chloride: $400 \mathrm{~g}$; antioxidant: $125 \mathrm{~g}$; magnesium: 80 g; zinc: 50 g; iron: 20 g; copper: 5 g; iodine: 1.2 g; selenium: $200 \mathrm{mg}$; cobalt: $200 \mathrm{mg}$.

TABle 2: Average daily values for meteorological parameters observed during the experimental period.

\begin{tabular}{lccc}
\hline Parameter & $08.00 \mathrm{~h}$ & $16.00 \mathrm{~h}$ & Average \\
\hline Dry-bulb temperature $\left({ }^{\circ} \mathrm{C}\right)$ & 26.4 & 34.1 & 30.2 \\
Wet-bulb temperature $\left({ }^{\circ} \mathrm{C}\right)$ & 25.3 & 30.9 & 28.1 \\
Relative humidity $(\%)$ & 94.2 & 83.8 & 89.0 \\
Temperature-humidity index & 85.2 & 131.1 & 108.1 \\
\hline
\end{tabular}

performance of broiler chickens during hot-dry season. The treatment had no significant $(P>0.05)$ effect on FI, WG, FCR, WI, SURV, DRE, BRE, GIZ, DRU, SHA, and THI. The values recorded were similar for the treatment group and the control. Effect of honey on bone strength and mineral deposition in tibiae of broiler chickens was presented in Table 4. There were no significant $(P>0.05)$ differences in tibial volume from broilers offered either honey or no honey. Magnesium content of tibiae was not $(P>0.05)$ different for the four treatment groups. However, treatment had significant $(P<0.05)$ effect on weight and density of tibiae. Broilers in $20 \mathrm{H}$ group had the heaviest tibiae $(10.2 \mathrm{~g})$, while the lightest were from $\mathrm{OH}$ group. The weight of tibiae
TABLE 3: Effect of honey on growth performance of broiler chickens during hot-dry season.

\begin{tabular}{lccccc}
\hline Parameter & $0 \mathrm{H}$ & $10 \mathrm{H}$ & $20 \mathrm{H}$ & $\mathrm{AA}$ & sem \\
\hline Feed intake (Kg/day/bird) & 0.101 & 0.100 & 0.099 & 0.099 & 0.0050 \\
Weight gain (Kg/day/bird) & 0.029 & 0.028 & 0.029 & 0.025 & 0.0030 \\
Feed conversion ratio & 4.73 & 3.64 & 3.84 & 4.13 & 0.547 \\
Water intake (L/day) & 2.34 & 2.27 & 2.37 & 2.38 & 0.079 \\
Survivability (\%) & 100.0 & 99.0 & 99.0 & 100.0 & 0.71 \\
Slaughtered weight (\%) & 92.4 & 93.8 & 88.6 & 93.8 & 2.23 \\
Dressed weight (\%) & 86.8 & 89.2 & 84.8 & 88.2 & 2.06 \\
Breast meat (\%) & 15.4 & 15.4 & 16.6 & 16.6 & 0.78 \\
Gizzard (\%) & 2.6 & 2.7 & 2.5 & 2.9 & 0.20 \\
Drumstick (\%) & 10.8 & 11.2 & 10.3 & 10.9 & 0.39 \\
Shank (\%) & 5.0 & 5.1 & 4.5 & 4.8 & 0.29 \\
Thigh (\%) & 10.3 & 10.8 & 10.2 & 10.4 & 0.61 \\
\hline
\end{tabular}

TABLe 4: Effect of honey on mineral deposition in tibiae of broiler chickens during hot-dry season.

\begin{tabular}{|c|c|c|c|c|c|}
\hline Parameter & $0 \mathrm{H}$ & $10 \mathrm{H}$ & $20 \mathrm{H}$ & AA & Sem \\
\hline Volume of tibiae (mL) & 6.4 & 8.2 & 8.2 & 6.8 & 0.62 \\
\hline Weight of tibiae (g) & $8.8^{\mathrm{b}}$ & $10.0^{\mathrm{a}}$ & $10.2^{\mathrm{a}}$ & $7.8^{\mathrm{c}}$ & 0.17 \\
\hline Density of tibiae $(\mathrm{g} / \mathrm{mL})$ & $1.4^{\mathrm{a}}$ & $1.2^{\mathrm{ab}}$ & $1.2^{\mathrm{ab}}$ & $1.1^{\mathrm{b}}$ & 0.09 \\
\hline Calcium (mg/g) & $118.5^{\mathrm{b}}$ & $117.6^{\mathrm{b}}$ & $120.2^{\mathrm{a}}$ & $120.3^{\mathrm{a}}$ & 0.32 \\
\hline Phosphorus (mg/g) & $77.9^{\mathrm{ab}}$ & $76.5^{\mathrm{b}}$ & $76.2^{\mathrm{b}}$ & $79.9^{\mathrm{a}}$ & 0.51 \\
\hline Magnesium (mg/g) & 4.9 & 4.7 & 4.9 & 4.8 & 0.05 \\
\hline
\end{tabular}

from broilers in $10 \mathrm{H}$ was similar to that of $20 \mathrm{H}$. In the same vein, calcium, and phosphorus deposition in bone was significantly $(P<0.05)$ affected by treatment. Broilers in $20 \mathrm{H}$ group had similar calcium content in bone to AA group. These were significantly higher than $0 \mathrm{H}$ and $10 \mathrm{H}$ groups. Broilers offered honey had significantly lower PHO content in tibiae than AA group, though the $\mathrm{PHO}$ content in $\mathrm{OH}$ group was not different from AA group.

Table 5 shows the effect of honey on physiological response and relative weight of organs in broiler chickens during hot-dry season. RT was not $(P>0.05)$ significantly affected by treatment. However, the effect of the treatment on PR $(P<0.001)$ and HR $(P<0.01)$ was highly significant. Addition of $20 \mathrm{H}$ honey to drinking water lowered PR (32.3 breaths per minute) in broiler chickens compared to $\mathrm{OH}$ (39.0 breaths per minute) though this was not different from $10 \mathrm{H}$ (35.4 breaths per minute). HR decreased linearly as honey treatment increases (from $0 \mathrm{H}$ to $20 \mathrm{H}$ ) Broilers offered $20 \mathrm{H}$ had lower $\mathrm{HR}$ compared to $0 \mathrm{H}$ and AA groups. The PR decreased gradually as concentration of honey in water increased. The relative weight of LIV, KID, LUN, SPL, BUR, and HEA was not $(P>0.05)$ affected by treatment. However, the relative weight of THY was significantly $(P<$ $0.05)$ increased by honey. $0 \mathrm{H}$ and $10 \mathrm{H}$ groups $(0.07$ and 
TABLE 5: Effect of honey on physiological responses and relative weight of organs of broiler chickens during hot-dry season.

\begin{tabular}{lccccc}
\hline \multirow{2}{*}{ Parameter } & \multicolumn{5}{c}{ Mean } \\
& $0 \mathrm{H}$ & $10 \mathrm{H}$ & $20 \mathrm{H}$ & AA & sem \\
\hline Rectal temperature $\left({ }^{\circ} \mathrm{C}\right)$ & 40.5 & 40.8 & 40.7 & 40.6 & 0.09 \\
Panting rate (breaths/minute) & $39.0^{\mathrm{a}}$ & $35.4^{\mathrm{ab}}$ & $32.3^{\mathrm{b}}$ & $39.2^{\mathrm{a}}$ & 1.52 \\
Heart rate (beats/minute) & $108.7^{\mathrm{a}}$ & $76.4^{\mathrm{bc}}$ & $72.5^{\mathrm{c}}$ & $95.2^{\mathrm{ab}}$ & 6.06 \\
Liver (\%) & 2.5 & 2.7 & 2.2 & 2.5 & 0.15 \\
Kidney (\%) & 0.02 & 0.02 & 0.02 & 0.03 & 0.003 \\
Lung (\%) & 0.60 & 0.81 & 0.61 & 0.63 & 0.066 \\
Spleen (\%) & 0.10 & 0.16 & 0.11 & 0.10 & 0.018 \\
Bursa (\%) & 0.04 & 0.06 & 0.05 & 0.06 & 0.015 \\
Thymus (\%) & $0.07^{\mathrm{b}}$ & $0.06^{\mathrm{b}}$ & $0.10^{\mathrm{a}}$ & $0.11^{\mathrm{a}}$ & 0.012 \\
Heart (\%) & 0.45 & 0.41 & 0.44 & 0.42 & 0.026 \\
\hline
\end{tabular}

$\overline{\mathrm{a}, \mathrm{b}, \mathrm{c}}$ Means with different superscripts in the same row differ significantly $(P<0.05)$.

$0.06 \%$, resp.) recorded lighter thymus than $20 \mathrm{H}(0.10 \%)$. The weight at $20 \mathrm{H}$ was similar to that of AA group.

\section{Discussion}

HS causes reduction in feed consumption and growth rate of broiler chickens and increases the death rate $[8,9]$. Singleton [28] reported that about $75 \%$ of the metabolizable energy consumed by the bird will be converted to body heat and required to be lost to the environment. Thus, reduction in feed intake is an important physiological adaptive mechanism to reduce HS. Reduction in feed intake consequentially results in deficiency in the essential nutrients. Howlider and Rose [29] and May et al. [30] reported that growth rate is reduced in broiler birds when environmental temperature rises because energy obtained from the small feed consumed is expended in panting. The result is that birds had lower final body weight. Efficacious intervention that is capable of improving these traits therefore must be put in place to optimize productivity in broiler production. In the present study, neither honey $(10 \mathrm{H}$ and $20 \mathrm{H})$ nor AA $(0.5 \mathrm{~g}$ vitamin $\mathrm{C} / \mathrm{L}$ water) was effective in improving the weight gain, feed intake, feed conversion ratio, and survival in broilers under hot-dry condition. Miraei-Ashtiani et al. [31] had earlier given a report similar to this. The authors found that there was no difference in weight gain, feed intake, feed conversion ratio and final liveweight offered feed supplemented with or without $200 \mathrm{ppm}$ vitamin C. The outcome of this present study is contrary to the report of [32] that dietary vitamin C improves growth performance in broilers. It is possible that the concentrations of honey and vitamin $\mathrm{C}$ used in this study were not sufficient.

In this study, the volume of tibia bones for broilers offered either honey or not remained the same. However, weight, density, and calcium content of the bone were improved by addition of honey to drinking water of heatstressed broiler chickens at high dose $(20 \mathrm{H})$. This might be adduced to improvement in calcium metabolism of the birds.
Mineral metabolism and deposition in bones are affected by HS in poultry [33]. Impaired growth of cartilage and bone was one of the effects of HS mentioned by [34] in a review on managing stress in broiler breeders. Corticosteroid hormones, the hormones released during episode of stress have strongly been implicated in mammalian osteoporosis [35]. These steroids have multitudes of effects on cells such as slowing cell division and differentiation. In mature animals, corticosteroids can affect remodeling, perhaps by preventing the recruitment of osteoblasts and causing bone to weaken by preventing normal bone formation. However, [36] reported that both male and female White Leghorns can maintain bone $\mathrm{Na}, \mathrm{K}, \mathrm{Ca}, \mathrm{Mg}, \mathrm{P}, \mathrm{Cu}, \mathrm{Zn}, \mathrm{Fe}, \mathrm{Mn}$, and percentage ash in ambient temperature ranging between 21.1 and $35.0^{\circ} \mathrm{C}$. HS causes depletion of vitamin $\mathrm{C}$ in animals. Vitamin $\mathrm{C}$ is required for conversion of 25 -hydroxy vitamin $D_{3}$ produced by the liver into the hormone calcitriol in the kidney. Calcitriol is essential in the regulation of calcium metabolism $[33,37]$. Therefore, the depletion of vitamin C during HS results in obstruction of calcium metabolism. Chung et al. [38] reported that hens fed Vitamin C supplemented feed had higher tibial bone breaking strength than those fed control diet though tibial bone weight and length were not affected by dietary treatments.

The panting and heart rate of broilers were reduced by honey, especially at $20 \mathrm{~mL}$ per litre water compared with other groups. This corroborates the work of [39] that panting rate was reduced in heat-stressed birds given vitamin $\mathrm{C}$. Some constituents of honey might be effective at adrenal cortex level where they may either inhibit secretion or release of corticosterone, the main stress hormone in chickens. Vitamin $\mathrm{C}$ had been reported to carry out the same functions in birds under stress conditions. Further studies should be carried out on the use of honey in broilers, especially on the constituents that are bioactive. It is possible that it contains some phyto-hormones that have control on contraction and relaxation of muscles of the heart and lungs.

Honey had effect only on the size of thymus out of all organs sampled. The relative weight of thymus to the live bodyweight was increased by $20 \mathrm{H}$ honey. The weight was similar to that of AA group. HS has been reported to inhibit immune functions in chickens [40-42]. Surgical removal of thymus (thymectomy) has been used to demonstrate its immunologic role [43]. Efficacy of Sb-Asper-C, a combined ascorbic acid and acetylsalicylic acid treatment in reducing the effects of HS was tested in broilers by [44]. The authors reported that the treatment increased the ratio of thymus to body weight. Actually, the thymus of heat-stressed chickens not supplemented with Sb-Asper-C was atrophied. Honey up to $20 \mathrm{~mL}$ per litre water reduced the effect of HS on thymus.

\section{Conclusion}

Addition of honey to drinking water of broiler chickens in this experiment neither affected the growth nor reduced the body temperature. However, at a dosage of $20 \mathrm{~mL}$ honey per litre water, the panting and heart rates were reduced in birds during hot spell. Honey may improve bone strength and immunity in heat-stressed broiler chickens. 


\section{References}

[1] S. Yahav, "Domestic fowl: strategies to confront environmental conditions," Avian and Poultry Biology Reviews, vol. 11, no. 2, pp. 81-95, 2000.

[2] D. Grieve, Heat Stress in Commercial Layers and Breeders., vol. 19, Iowa HLST, Technical Bulletin Hy-Line International, 2003.

[3] N. Chaiyabutr, "Physiological reactions of poultry to heat stress and methods to reduce its effects on poultry production," Thai Journal of Veterinary Medicine, vol. 32, no. 2, pp. 17-30, 2004.

[4] D. R. Charles, "Responses to the thermal environment," in Poultry Environment Problems, A Guide To Solutions, D. A. Charles and A. W. Walker, Eds., pp. 1-16, Nottingham University Press, Nottingham, UK, 2002.

[5] M. O. Abioja, Temperature-humidity effects on egg fertility and evaluation of vitamin $C$ and cold water on broiler growth in hot season [Ph.D. thesis], Department of Animal Physiology, University of Agriculture, Abeokuta, Nigeria, 2010.

[6] S. M. Shane, "Factors influence health and performance of poultry in hot climates," Poultry Biology, vol. 1, pp. 247-269, 1988.

[7] O. Altan, A. Altan, I. Oguz, A. PabuAscuoglu, and S. Konyalioğlu, "Effects of heat stress on growth, some blood variables and lipid oxidation in broilers exposed to high temperature at an early age," British Poultry Science, vol. 41, no. 4, pp. 489-493, 2000.

[8] L. Hai, D. Rong, and Z. Y. Zhang, "The effect of thermal environment on the digestion of broilers," Journal of Animal Physiology and Animal Nutrition, vol. 83, no. 2, pp. 57-64, 2000.

[9] Z. H. M. Abu-Dieyeh, "Effect of chronic heat stress and longterm feed restriction on broiler performance," International Journal of Poultry Science, vol. 5, pp. 185-190, 2006.

[10] J. T. Brake, Stress and Modern Poultry Management: Animal Production Highlights, Hoffman-La Roche, Basle, Switzerland, 1987.

[11] J. Post, J. M. J. Rebel, and A. A. H. M. Ter Huurne, "Physiological effects of elevated plasma corticosterone concentrations in broiler chickens. An alternative means by which to assess the physiological effects of stress," Poultry Science, vol. 82, no. 8, pp. 1313-1318, 2003.

[12] R. Vakili, A. A. Rashidi, and S. Sobhanirad, "Effects of dietary fat, vitamin $\mathrm{E}$ and zinc supplementation on tibia breaking strength in female broilers under heat stress," African Journal of Agricultural Research, vol. 5, no. 23, pp. 3151-3156, 2010.

[13] M. O. Abioja, O. A. Osinowo, O. F. Smith, D. Eruvbetine, and J. A. Abiona, "Evaluation of cold water and vitamin C on broiler growth during hot-dry season in south-western Nigeria," Archivos De Zootecnia, vol. 60, pp. 1095-1103, 2011.

[14] S. L. Pardue and J. P. Thaxton, "Ascorbic acid in poultry: a review," World's Poultry Science Journal, vol. 42, pp. 107-123, 1986.

[15] K. Sahin, N. Sahin, and O. Kucuk, "Effects of chromium, and ascorbic acid supplementation on growth, carcass traits, serum metabolites, and antioxidant status of broiler chickens reared at a high ambient temperature $\left(32^{\circ} \mathrm{C}\right)$," Nutrition Research, vol. 23, no. 2, pp. 225-238, 2003.

[16] K. Z. Mahmoud, F. W. Edens, E. J. Eisen, and G. B. Havenstein, "Ascorbic acid decreases heat shock protein 70 and plasma corticosterone response in broilers (Gallus gallus domesticus) subjected to cyclic heat stress," Comparative Biochemistry and Physiology B, vol. 137, no. 1, pp. 35-42, 2004.

[17] R. A. Sobayo, Effect of ascorbic acid supplementation on the performance and haematological profile of pullets and layers [Ph.D. thesis], Department of Animal Nutrition, University of Agriculture, Abeokuta, Nigeria, 2005.

[18] C. A. Mbajiorgu, J. W. Ng'ambi, and D. Norris, "Effect of time of initiation of feeding after hatching and influence of dietary ascorbic acid supplementation on productivity, mortality and carcass characteristics of ross 308 broiler chickens in South Africa," International Journal of Poultry Science, vol. 6, no. 8, pp. 583-591, 2007.

[19] V. Ramnath, P. S. Rekha, and K. S. Sujatha, "Amelioration of heat stress induced disturbances of antioxidant defense system in chicken by Brahma Rasayana," Evidence-Based Complementary and Alternative Medicine, vol. 5, no. 1, pp. 7784, 2008.

[20] Y. J. Chen, A. C. Huang, H. H. Chang et al., "Caffeic acid phenethyl ester, an antioxidant from propolis, protects peripheral blood mononuclear cells of competitive cyclists against hyperthermal stress," Journal of Food Science, vol. 74, no. 6, pp. H162-H167, 2009.

[21] J. Wang, G. M. Jin, Y. M. Zheng, S. H. Li, and H. Wang, "Effect of bee pollen on development of immune organ of animal," Zhongguo Zhong Yao Za Zhi, vol. 30, pp. 1532-1536, 2005.

[22] G. F. Zhang, Z. B. Yang, Y. Wang, W. R. Yang, S. Z. Jiang, and G. S. Gai, "Effects of ginger root (Zingiber officinale) processed to different particle sizes on growth performance, antioxidant status, and serum metabolites of broiler chickens," Poultry Science, vol. 88, no. 10, pp. 2159-2166, 2009.

[23] M. A. Akanmu, C. Echeverry, F. Rivera, and F. Dajas, "Antioxidant and neuroprotective effects of Nigerian honey," in Proceedings of the Nueroscience Meeting Planner, Washington, DC, USA, 2009.

[24] F. O. Adetuyi, T. A. Ibrahim, Jude-Ojei, and G. A. Ogundahunsi, "Total phenol, tocopherol and antibacterial quality of honey Apis mellifera sold in owo community, Ondo State, Nigeria," Electronic Journal of Environmental, Agricultural and Food Chemistry, vol. 8, no. 8, pp. 596-601, 2009.

[25] B. O. Omafuvbe and O. O. Akanbi, "Microbiological and physico-chemical properties of some commercial Nigerian honey," African Journal of Microbiology Research, vol. 3, no. 12, pp. 891-896, 2009.

[26] F. M. Adebiyi, I. Akpan, E. I. Obiajunwa, and H. B. Olaniyi, "Chemical/physical characterization of Nigerian honey," Pakistan Journal of Nutrition, vol. 3, pp. 278-281, 2004.

[27] SYSTAT, Systat Analytical Computer Package (Version 5. 0), Systat Inc., 1992.

[28] R. Singleton, "Hot weather broiler and breeder management," Asian Poultry Magazine, pp. 26-29, 2004.

[29] M. A. R. Howlider and S. P. Rose, "Temperature and the growth of broilers," World's Poultry Science Journal, vol. 43, pp. 228-237, 1987.

[30] J. D. May, B. D. Lott, and J. D. Simmons, "The effect of air velocity on broiler performance and feed and water consumption," Poultry Science, vol. 79, no. 10, pp. 1396-1400, 2000.

[31] S. R. Miraei-Ashtiani, P. Zamani, M. Shirazad, and A. Zareshahned, "Comparison of the effect of different diets on acute heat stressed broilers," in Proceeding of the 22nd World Poultry Congress, p. 552, Istanbul, Turkey, 2004.

[32] W. B. Gross, "Effect of ascorbic acid on the mortality of Leghorn-type chickens due to overheating," Avian Diseases, vol. 32 , no. 3, pp. 561-562, 1988 . 
[33] J. Brake, Stress and Modern Poultry Management. Animal Production Highlights 2/87, Hoffmann-La Roche, Basle, Switzerland, 1988.

[34] A. G. Rosales, "Managing stress in broiler breeders: a review," Journal of Apllied Poultry Research, vol. 3, pp. 199-207, 1994.

[35] I. R. Reid, "Glucocorticoid-induced osteoporosis: assessment and treatment," Journal of Clinical Densitometry, vol. 1, no. 1, pp. 65-73, 1998.

[36] K. V. Vo, M. A. Boone, and A. K. Torrence, "Electrolyte content of blood and bone in chickens subjected to heat stress," Poultry science, vol. 57, no. 2, pp. 542-544, 1978.

[37] H. Weiser, M. Schlachter, and R. Fenster, "The importance of vitamin C for the metabolism of vitamin D3 in poultry," in Proceedings of the 18th World Poultry Congress, p. 831, Nagoya, Japan, 1988.

[38] M. K. Chung, J. H. Choi, Y. K. Chung, and K. M. Chee, "Effects of dietary vitamins $\mathrm{C}$ and $\mathrm{E}$ on egg shell quality of broiler breeder hens exposed to heat stress," Asian-Australasian Journal of Animal Sciences, vol. 18, no. 4, pp. 545-551, 2005.

[39] H. R. Kutlu and J. M. Forbes, "Changes in growth and blood parameters in heat-stressed broiler chicks in response to dietary ascorbic acid," Livestock Production Science, vol. 36, no. 4, pp. 335-350, 1993.

[40] D. Curca, V. Andronie, and I. C. Andronie, "The effect of ascorbic acid on poultry under thermal stress," in Proceedings of the 3rd International Congress of Pathophysiology, Lahti, Finland, June 1998.

[41] D. Curca, M. D. Codreanu, A. Pop, I. Codreanu, and C. P. Constantinescu, "Ascorbic acid level like redox system in parasitic disease in animal blood, liver and adrenal glands," Simpozionul de Fiziopatologie, Craiova, vol. 4-5, pp. 38-41, 2003.

[42] M. M. Mashaly, G. L. Hendricks, M. A. Kalama, A. E. Gehad, A. O. Abbas, and P. H. Patterson, "Effect of heat stress on production parameters and immune responses of commercial laying hens," Poultry Science, vol. 83, no. 6, pp. 889-894, 2004.

[43] D. Panigraphi, G. L. Waxler, and V. H. Mallman, "The thymus in the chicken and its anatomical relationship to the thyroid," Journal of Immunology, vol. 107, no. 1, pp. 289-292, 1971.

[44] B. Anwar, S. A. Khan, A. Maqbool, and K. A. Khan, "Effects of ascorbic acid and acetylsalicylic acid supplementation on the performance of broiler chicks exposed to heat stress," Pakistan Veterinary Journal, vol. 24, pp. 109-111, 2004. 

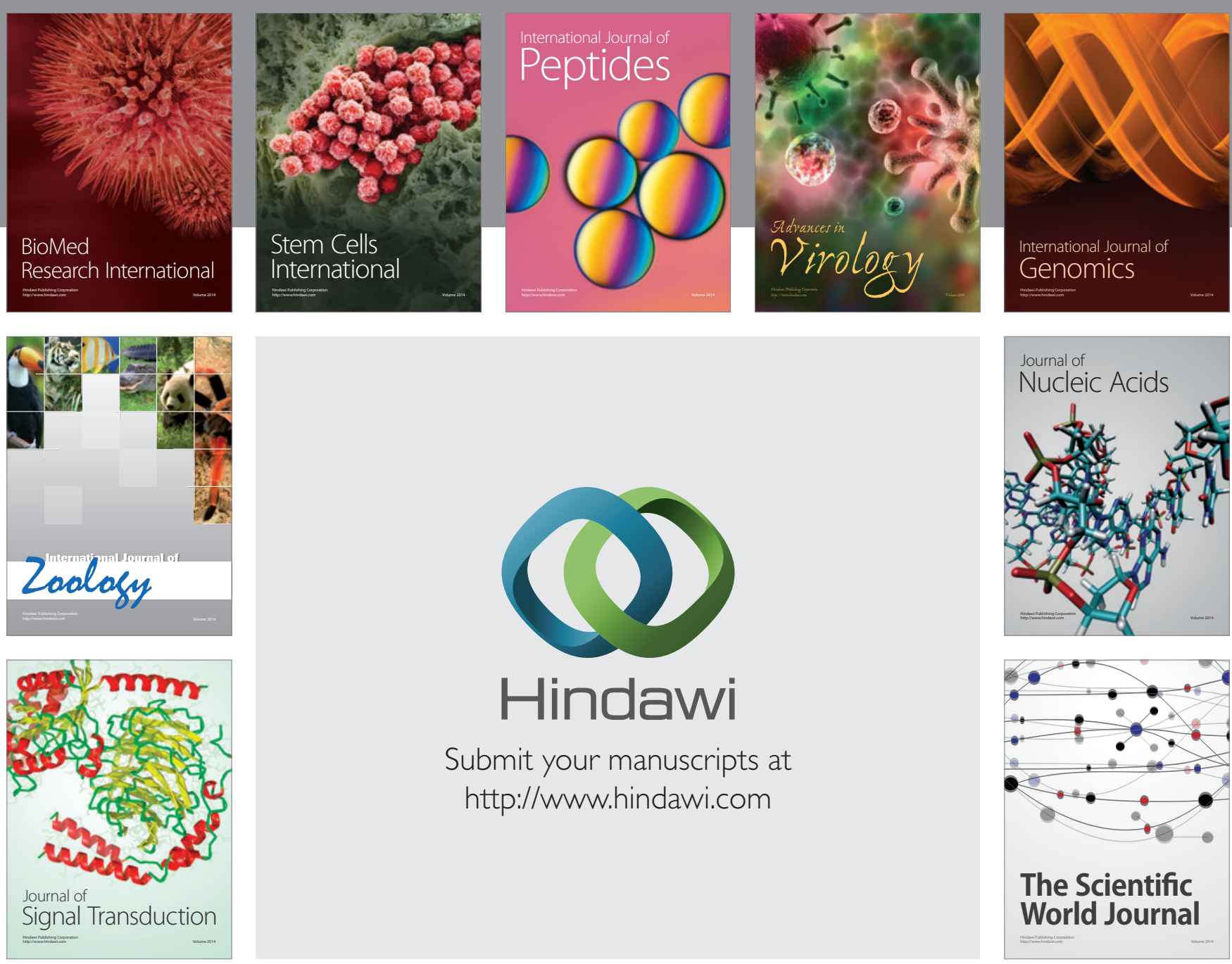

Submit your manuscripts at

http://www.hindawi.com
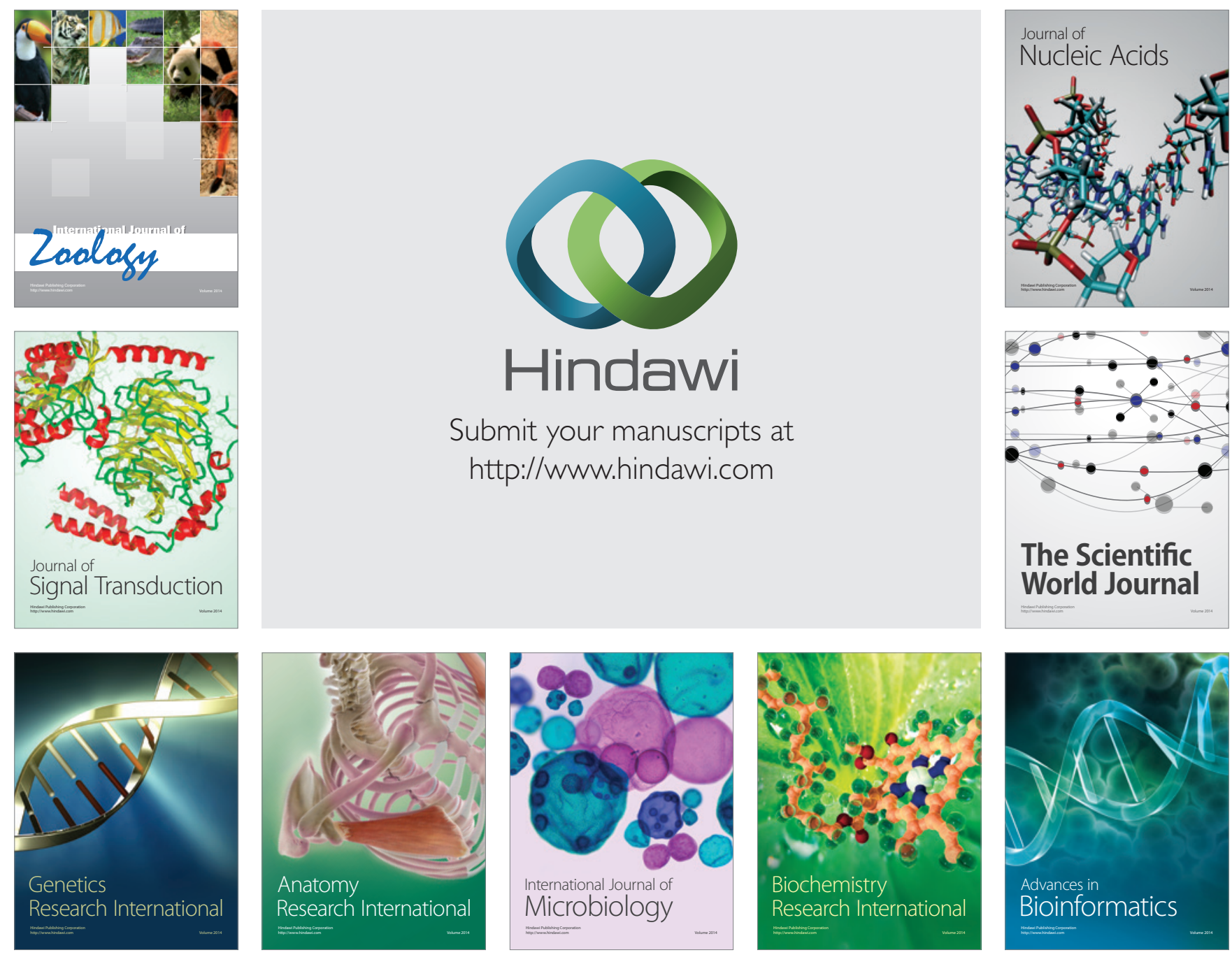

The Scientific World Journal
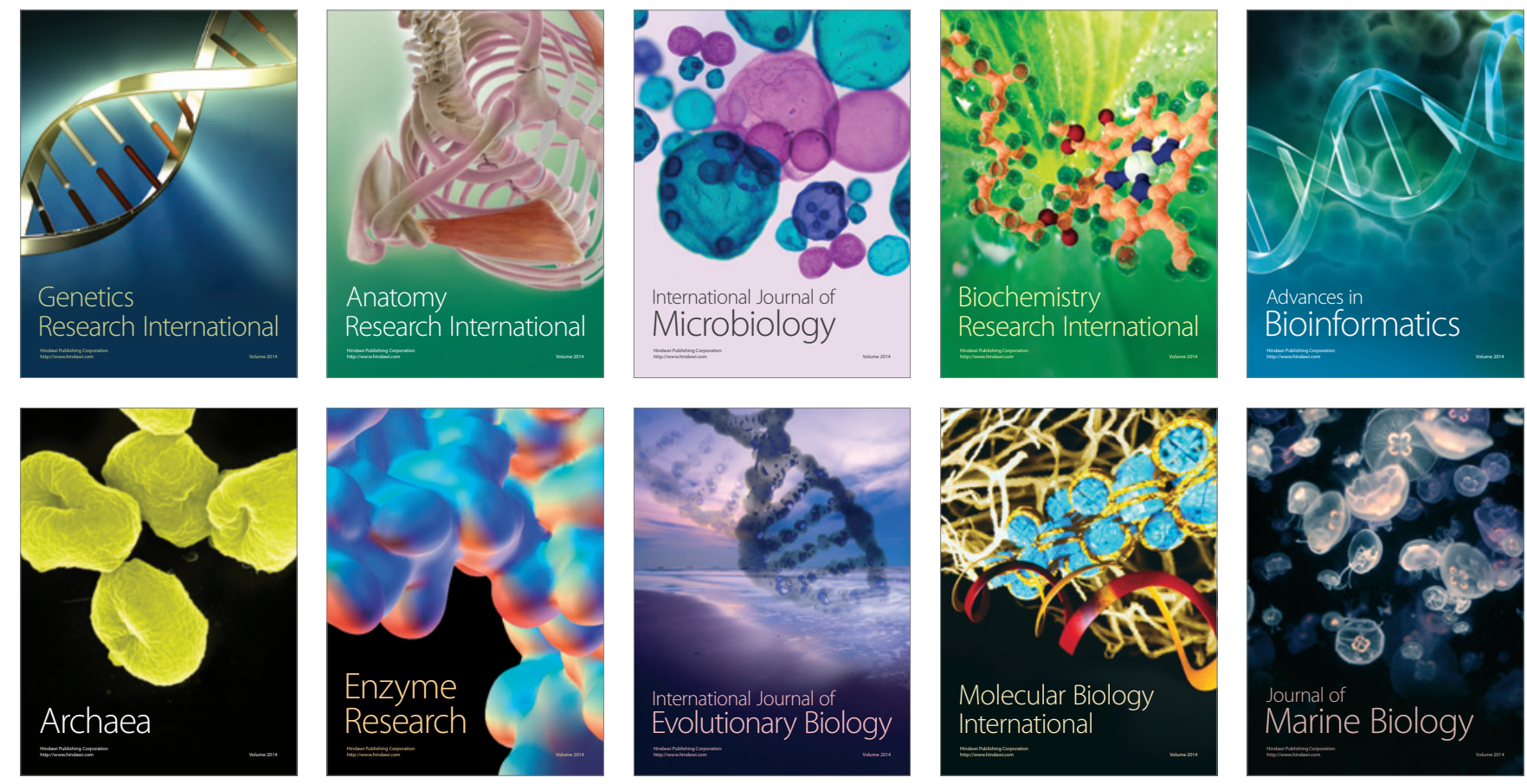